\title{
Rescaling water management and governance under new city-regionalism
}

\author{
L. A. Nicol \\ Department of Economics, University of Lethbridge, Canada
}

\begin{abstract}
In 2006, seventeen municipalities in the Calgary region of Canada embarked on a major initiative to develop a long-range, coordinated approach to land use planning and water-sharing under a new regional governance framework that was primarily driven by sustainability. The water-sharing component would see water from the central city being provided to surrounding water-stressed municipalities under an integrated water resource management plan. Called the Calgary Regional Partnership (CRP), this initiative is a highly complex and dynamic rescaling process involving multiple municipalities and water planning organizations. Water governance is couched within a broader ecological and economic city-region governance framework. While the academic literature speaks of city-regions as being privileged sites for new forms of governance, it also warns of significant challenges in their development and implementation. In this early stage in a planned research program, this paper will provide a literature review of three layers of rescaling pertinent to the case study: rescaling city-regions, rescaling ecological management, and rescaling water management. In situating the CRP within this literature, the paper underscores that partnership processes can be as daunting as they are ambitious and can cast doubts on the potential of implementing regional solutions to water management issues.

Keywords: rescaling, regional governance, integrated water management, city regions, water sharing.
\end{abstract}

\section{Introduction}

Multiple processes of rescaling are converging within the CRP, broadly encompassing economic and resource management of a city-region. At the cityregion level the CRP seeks to forge a partnership between a central city and a 
multitude of diverse municipalities on the periphery. Its impetus and legislative mandate are derived from the province's Land Use Framework (LUF) of 2006. When the CRP was initiated there were seventeen municipalities involved in the process, which were represented by elected civic council members. The primary objective of the partnership is decidedly ecological, driven by the normative concept of sustainability. Economic objectives, couched within sustainability, are encompassed within a very broad framework that ultimately seeks to manage economic development, land, water and wastewater, and transportation under a 75-year plan. Within the wider context, the CRP is situated within a large watershed within which there has been at play the rescaling of water management and governance for several years. This rescaling has been established on a completely different platform, not driven by the LUF but the province's Water for Life Strategy of 2003. The process of managing water is on a watershed basis under an integrated water resource management (IWRM) framework, and involves Watershed Planning and Advisory Councils (WPAC) and various smaller watershed partnerships have been given the task of developing watershed management plans and engaging in stewardship activities in the watershed. In addition to the linkage across municipalities, the intersection of the CRP with the water advisory councils and other watershed partnerships forms the second connection in this complex affiliation.

After three years of planning, three large rural counties pronounced their dissatisfaction and ultimate departure from the CRP. In a highly public statement made in June, 2009, they indicated they could not accept the land-use structure, annexation provisions and the voting structure. Principles and approaches to accessing regional water were also at issue. Underscoring ongoing conflict within the CRP, in December, 2011 another municipality defected from the partnership expressing concern over the CRP becoming a fourth level of government. For the remaining members of the CRP, implementation has been delayed and planning continues.

\section{Background}

Within the next 75-year period, it is anticipated that the region's population will increase from about 1.2 million to 2.8 million people, thus adding 1.6 million new residents and the attendant stress on land and water resources. To minimize the human footprint, the Calgary regional plan seeks to reduce the region's residential land requirements from a forecasted 125,000 extra hectares to 45,000 hectares with a corresponding decrease in the cost of infrastructure to these areas. In addition to land management, the plan has a water-sharing component that, if implemented, will have a significant bearing on how water is managed in the water stressed region. The Bow River Basin in which the Calgary region is situated, is $46 \%$ allocated, with irrigation accounting for $72 \%$ of allocations and municipalities representing $20 \%$ [1]. Pressure on and natural water system in the region was unrelenting until 2005 when the province took the unprecedented step to close the Bow River Basin to applications for new water licenses. The closure has meant that new water demands have to be met by reallocating existing 
licenses. Although the practice of buying and selling water licenses on both a temporary and permanent basis is permitted through legislation, the practice is not widespread and some sales have been highly controversial. Ghitter and Smart [2] note: "The (lack of) availability of water for development....has been permanently embedded as a factor for all future development in the region" [p. 637].

Unfortunately, when they were able to do so, municipalities in the Calgary region did not apply for water licenses that would be large enough to accommodate their long-term growth, hence more than half the region will face a water shortage by 2030 [3]. Unlike its surrounding municipalities, however, the City of Calgary has significant water license capacity, enough to accommodate three million people, about three times the city's current population. In aggregated, the region has sufficient water supply capacity to meet long-term projected municipal demands to 2075 and under the CRP Calgary is willing to share its water license, managed through a water utility. If this plan were implemented, use of water in the region would be vastly accelerated. Rather than accommodating incremental urban growth, Calgary's licenses would be used to accommodate both population and economic growth of the entire region.

\section{Literature review}

\subsection{Rescaling city-regions}

Neo-liberalism and globalization have had significant effects on the scales by which a host of institutions now operate. Rescaling or "making the size more appropriate" is expressed unevenly and in diverse institutional and political forms $[4,5]$. As globalization has become widespread, city-regions have gained more prominence [6]. City-region theory centres on the notion that "the territorial basis and organizational architecture of the global economy is now a mosaic of globally connected city-regions rather than nations" [7, p. 179].

There are major implications for the ways in which cities and regions are governed. The old model of a central city core surrounded by suburban satellite clusters is becoming increasingly obsolete as city-regions are transformed [8]. These are the "powered-up" sites in which policy options are generated [7, p. 652]. Resultant institutions have little resemblance to traditional urban policy machines which focused on infrastructure, housing, and transportation and are instead oriented toward the problem of coordination of urban production systems, dependent on consent of many different individuals and groups and requiring a high degree of social and political engagement [9].

The growth in the city-regions raises issues of new forms of governance under which they are formed and managed. Governance "conveys the notion that existing institutions can be harnessed in new ways, that cooperation can be carried out on a fluid and voluntary basis among localities and that people can best regulate themselves through horizontally linked organizations" [10, p. 161]. Local governments are but one agent in this mix. There are coalitions and networks organized across a range of spatial scales which involve co-operation, 
interdependencies, a multiplicity of actors, and networks that seek access to various resources necessary to create the capacity to govern and achieve policy goals $[7,11,12]$.

While new opportunities emerge, others are curtailed as rescaling necessarily entails disruption and re-composition of the networks of power that tie political actors together within and across scales, including the city-region [13]. Ultimately the ability of those regions to take advantage of economic opportunities will depend on their ability to overcome internal divisions and to organize and act as coherent entities [14, 15]. Ostrom [16] stresses tailoring partnership solutions to the individual municipalities and honouring community identity and expertise.

In city-regions, divergent political, economic and ideological agendas, ranging from economic growth, environmental sustainability to social justice, have resulted in ongoing struggles among diverse actors, alliances and institutions seeking to manage a widely diverse set of issues [8]. Ward and Jonas [17] suggest the process of re-scaling is best understood as an ongoing struggle for control of space. Foster [18] predicts that the greater the similarity between people and places within a region, the more apt they are to forge alliances.

Studies of voluntary, cooperative city-regions partnerships in Canada and have found considerable evidence of the notion of struggle over control of space. Collin, et al. [19] considered ten middle-sized cities in Canada and found no real city-region scope to strategic planning exercises. Absent was any institutional, political or territorial recognition of a city-region, municipal planning practices or collective learning towards a city-region approach. The presence of a major municipal actor, the central city, seemed to transpire against regional approaches to issues [19]. Similarly, Nelles' [15] study of the Toronto city-region found a "strong city, weak region" where power asymmetries between Toronto and the region fuel regional tensions. Organizations operate like localized silos. Few leaders have emerged as champions of regional causes or solutions and no coherent regional identity has developed [15]. Leibovitz [20] studied four Canadian cities known as the technological triangle (Cambridge, Guelph, Kitchener and Waterloo) and their unsuccessful attempt at collaborative economic development. The study found that in these cities with liberal political economies there is a much stronger tradition of competitive rather than collaborative behaviour presenting a formidable task to create the appropriate collaborative institutional designs [20]. Major difficulties include reluctance by local authorities to given up whatever powers still remain, failure to develop relationships of trust between local authorities and the regional level, concerns involving fair shares of incoming investment, and tension between the public and private sectors [20].

\subsection{Rescaling ecological management}

The regional approach to ecological management is based on the notion that management of natural environmental ecosystems involves larger spatial scales than individual local areas, especially in relation to water and land [21, 22]. In addition, ecological governance, like governance in general, is transitioning 
under the belief that governments are not, and cannot be, the only source of environment decision making authority [21, 22]. Ecological and social systems are interconnected and thus few environmental challenges can be resolved without governance arrangements recognizing these relationships [23].

Normative concepts such as sustainability involve ideological and political questions rather than simply ecological and economic ones [24]. Social and cultural factors are instrumental in defining and shaping governance formations. Questions relate to who is in control, who sets the agenda, who allocates resources, who mediates disputes, and who sets the rules of the game [25]. As a result, numerous ecological governance models exist [26]. Models may have multiple centres of decision making, many mechanism for coordinated action, authority may be distributed with networks or nodes of actors linked across scales [23].

British studies of regional ecological management are more common than Canadian studies. While et al. [27] studied two English regions and found that potential barriers include: past traditions of regional collaboration or conflict that may continue to influence the effectiveness of partnerships; accountability issues; and standard administrative boundaries that do not fit with the biological boundaries of water catchment-based areas [27]. In examining regional development agencies in Britain, Gibbs and Jonas [28] found them to be sites of struggles around economic and environmental issues and found regionalization of environmental policy to be an uneven process. An additional empirical study by Gibbs et al. [29] found that while sustainability issues are important, they are rarely a driving concern in any locality and they are often in conflict with economic development.

\subsection{Rescaling water management}

It has been widely acknowledged that government decision making has been replaced by multiscale, polycentric governance which recognizes that a large number of stakeholders now contribute to the management of water [30]. Integrated water resource management (IWRM) has been widely advocated in co-ordinating water, land and related resources. But integrating both natural and human systems under IWRM requires an unprecedented level of cooperation [31]. Social capital theory tells us that new opportunities for multilevel cooperation and learning can be created. But while social capital can be strengthened, it can also be diluted [32]. In a world characterized by uncertainty and change, Pahl-Wostl [33] advocates adaptive management - learning to manage by managing to learn. Actors need to rethink and renegotiate their assumptions, strive to answer good questions, take into account differing perspectives and avoid lock-in [33].

Two themes have consistently been advocated in the water policy literature that the watershed is the appropriate scale for organizing water management and second, since decision making structures at the watershed level generally do not exist, they should be created [34]. However watersheds are highly complex phenomena and answers to key questions are politically charged. Water management issues are rooted in seemingly infinite ecological, social and 
political interactions across temporal and spatial scales; they are highly complex, context-dependent, socially constructed and technically uncertain [34-37]. Fundamentally they involve a relationship between water and social power [38].

Numerous Canadian studies demonstrate why water management today, with its multi-layered, multi-purpose, multi-actor dimensions, is so difficult. In a study of IWRM in Ontario and Nova Scotia, Canada, Cervoni et al. [39] find that neither province has achieved the ideal IWRM due to lack of coordination, water resources crossing political boundaries, constitutional responsibilities causing fragmentation and lack of clarity in water management and responsibilities. Ferreyra et al. [37] studied water quality protection in Ontario, and found that there needs to be more flexible ways of linking watershed imperatives to other socially and politically relevant scales. Mitchell's [40] research underscores that IWRM plans often become orphaned because they do not have any statutory basis. His review demonstrates how IWRM can enhance its effectiveness by becoming linked to statutory-based regional and land-use planning. Some call into question the workability of the IWRM paradigm, full-stop [41]. Carter et al. [42] study IWRM in Ontario from the perspective of integrating water and land management. While increasing stakeholder involvement is a central tenant of IWRM, as more people are involved and as efforts are made to coordinate across sectors including land, the likelihood of conflicts increased. Their case studies found a host of issues, among them time constraints, lack of coordination, and lack of stakeholder involvement in decision making. Leach and Pelkey [43] reviewed 37 empirical studies on watershed partnerships and, using factor analysis to group themes, found one of the most significant findings was the importance of effective leaders and facilitators and interpersonal trust.

\section{The challenge of the Calgary regional partnership}

Foster predicts that the greater the similarity between people and places within a region, the more apt they are to forge alliances [18]. Based on various indicators, Sorensen [44] found evidence of a relatively high degree of interdependence in the Calgary region. But despite apparent connections, the region exhibits certain characteristics that the literature notes can become highly problematic in developing governance partnerships. These factors relate to lack of trust, inability to relinquish power, historic tensions, weak regional identity, competitive attitudes, and administrative structures that promote and perpetuate division.

Tensions and distrust around managing growth in the Calgary region go back decades. Calgary is one of the very few cities in North America that has been able to expand its boundaries through incremental annexations. These annexations were highly controversial and generated deep opposition [2]. Power over development was for decades under urban control but the passage of the Municipal Government Act of 1995 shifted control to individual municipalities. In recent years as the population in the region boomed, individual municipalities forged ahead with development with no regional scope or coordination with Calgary, escalating regional tensions [2]. 
In addition to land, water has also been the source of contention. The discovery of bovine spongiform encephalopathy (BSE) in 2003 closed many international borders to Canadian cattle and prompted the production of local meat packing facilities. Regional tensions were intensified when such a facility was located in Rocky View County. Instead of extending existing water and wastewater infrastructure from the City of Calgary, the County deliberately found its own water supply and built its own infrastructure [2].

Results of a recent study of the CRP, based on interviews and survey data, are consistent with other points raised in the literature. The study found that municipalities exhibited an initial eagerness, but the CRP process has floundered in attempting to translate enthusiasm and principles into concrete, on-the-ground action [44]. Concerns over loss of community identity were prevalent: “...fear of having local concerns overshadowed by regional or urban matters....Fears about the future, funding, failures and forced partnerships were also frequently raised" [44, p. 23].

Although Ostrom [16] stresses tailoring partnership solutions to the individual municipalities and honouring community identity and expertise, there are overarching aspects of the CRP plan that would not be altered to satisfy the counties that left the partnership in 2009. The CRP said:

"Although the principles and values of the plan, along with the plan's settlement pattern, was developed collaboratively with all municipalities, fundamental issues raised by the rural members could not be bridged without compromising the principles and rigorous analysis that created the plan" $[45$, p. 1$]$.

The study also found that difficulties with the CRP process were exacerbated by fear of others' agendas which were often inhered along urban-rural lines [44]. Land use planning proved to be the most contentious and irresolvable issue. Although perhaps not as contentious, principles and approaches to accessing regional water were also at issue. This related to access to water by medium density rural development, hamlets and villages. There were also issues over enhancing water storage capacity by building reservoirs in the watershed.

Unequal power in decision-making was a dominant concern [44]. In 2009 the dissenting counties strongly opposed the voting structure of the partnership. The counties stated:

"We stand here today with $100 \%$ of the rural land-base and natural capital, or - put differently $-100 \%$ of the land base for growth within the region. Yet the majority of CRP members appear indifferent to our outstanding concerns that we have no voice within the proposed voting structure to influence regional decision, both of which underscore a considerable flaw within the current plan. As it is drafted right now, this is a plan that for all intents and purposes silences $100 \%$ of the region's rural landowners" [46, p. 13-14].

In addition to the challenge of establishing the CRP governance framework, the CRP is obligated to cooperate with organizations and institutions involved in 
water planning in its large watershed, where rescaling of water management has been taking place for several years. Within the Bow River Basin there are no less than 15 sub-basins. There is one over-arching WPAC (the Bow River Basin Council) and at least four additional watershed partnerships. Unfortunately there had been a litany of issues with watershed-based organizations in Alberta. The WPAC's have little provincial direction as to what they must accomplish; they are supposed to be leaders in watershed planning but can only provide advice; they are expected to undertake the difficult, if not impossible task, of coordinating with decision-makers across the land, water and other resource management spectra; and WPACs have suffered from inadequate resources [47]. The advent of the omnipotent LUF (subsequently enshrined in legislation), and the subsequent creation and elevation of regional advisory councils to facilitate multi-stakeholder input, the WPACs have been left marginalized. In addition, and most importantly, regional plans like the CRP are supposed to take into account watershed plans but there is no formal connection to WPAC's.

\section{Conclusions}

The academic literature assists in understanding certain features of the CRP and its development. On the face of it, numerous benefits can be captured in rescaling city-region economic, ecological and water governance. All rescaling processes and institutional outcomes will be unique. In common, however, is that rescaling processes are fraught with challenges that come from the high level of complexity and social and political engagement required. In the early stage of this study, a general understanding of the CRP process presents a case where the original partners were able to develop a long-term vision of the region (referred to by some as the 'low hanging fruit') but the partnership began to flounder on the details of its implementation. Several additional observations can be made. If, as the literature notes, city-regionalism is best understood as an ongoing struggle for control of space [17], then the irreconcilable issues over land management that emerged should not be surprising. In addition, given that studies have shown that the presence of a dominant central city results in problematic power asymmetries [15, 20], Calgary's historic and ongoing dominance in the region would transpire against the partnership. Despite entering into the process in good faith, some municipalities could not shake their longstanding distrust. Finally, water-sharing under a new water governance structure within the CRP provides a unique regional solution to water management problems in the province. However, despite the appeal of providing a long-term water supply to municipalities, the defection of several partners reduces the regional scope originally envisaged. In its reduced form, the regional plan has yet to be successfully implemented, including the concept of integrated water resource management.

The CRP is highly ambitious. It is also highly complex and challenging. Ultimately the complex and challenging nature of city-region economic, ecological and water rescaling cannot be underestimated and expectations should be adjusted accordingly. 


\section{References}

[1] Alberta Environment, What is water used for in the South Saskatchewan River Basin? Information Sheet. Author: Edmonton, Alberta, 2007.

[2] Ghitter, G. \& Smart, A., Mad cows, regional governance, and urban sprawl. Urban Affairs Review, 44(5), pp. 617-644, 2009.

[3] Pernitsky, D.J., \& Guy, N.D., Closing the South Saskatchewan River Basin to new water licenses: Effects on municipal water supplies. Canadian Water Resources Journal, 35(1), pp. 79-92, 2010.

[4] Brenner, N., The urban question as a scale question: Reflections on Henri Lefebvre, urban theory and the politics of scale. International Journal of Urban and Regional Research, 24, pp. 361-78, 2000.

[5] Jessop, B., Post-Fordism and the state (Chapter 8). Post-Fordism: A Reader, ed. A. Amin, Blackwell Publishers Inc.: Oxford, pp. 251-279, 1994.

[6] MacLeod, G., \& Goodwin, M., Space, scale and state strategy- rethinking urban and regional governance. Progress in Human Geography, 23 (4), pp. 503-527, 1999.

[7] McGuirk, P., The political construction of the city-region: notes from Sydney. International Journal of Urban and Regional Research, 31 (1), pp. 179-187, 2007.

[8] Brenner, N., Decoding the newest "Metropolitan Regionalism" in the USA: A critical overview. Cities, 19 (1), pp. 3-21, 2002.

[9] Scott, A.J., \& Storper, M., Regions, globalization, development. Regional Studies, 37 (6\&7), pp. 579-593, 2003.

[10] Savitch, H.V., \& Vogel, R.K., Paths to new regionalism (Introduction). Symposium on the new regionalism and its policy agenda, State and Local Government Review, eds. H.V Savitch \& R.K. Vogel, University of Georgia: Georgia, pp. 158-168, 2000.

[11] Amin, A., \& Thrift, N., Globalisation, institutional 'thickness' and the local economy (Chapter 4). Managing Cities: The New Urban Context, eds. P. Healey, A. Cameron, S. Davoudi, S. Graham \& A. Madani-Pour, John Wiley and Sons: Chichester, pp. 91-108, 1995.

[12] Healey, P., An institutional model of the development process. Journal of Property Research, 9, pp. 33-44, 1992.

[13] McCann, E., Framing space and time in the city: urban policy and the politics of spatial and temporal scale. Journal of Urban Affairs, 25 (2), pp. 159-178, 2003.

[14] Frisken, F., \& Norris, D., Regionalism reconsidered. Journal of Urban Affairs, 23 (5), pp. 467-478, 2002.

[15] Nelles, J., Cooperation and Capacity? Exploring the sources and limits of city-region governance partnerships. Paper prepared for the annual meeting of the American Political Science Association, Toronto, Canada, September, 2009. 
[16] Ostrom, E., Polycentric systems as one approach for solving collective action problems, Online. http://dlc.dlib.indiana.edu/dlc/bitstream/handle /10535/4417/W08-6_Ostrom_DLC.pdf?sequence=1, 2008.

[17] Ward, K., \& Jonas, A., Competitive city-regionalism as a politics of space: a critical reinterpretation of the new regionalism. Environment and Planning A, 36, pp. 2119-2139, 2004.

[18] Foster, K., Regional Impulses. Journal of Urban Affairs, 19 (4), pp. 375403, 1997.

[19] Collin, J.P., Breux, S. \& Rivard, M., Metropolitanization and the re-scaling of metropolitan public policies. The Canadian Experience. Paper presented to the international workshop "Governance and spatial discontinuities: Reterritorialization or a new polarization of metropolitan spaces?" Montreal, 2006.

[20] Leibovitz, J., Institutional barriers to associative city-region governance: the politics of institution-building and economic governance in 'Canada's Technology Triangle’. Urban Studies, 40 (13), pp. 2613-2642, 2003.

[21] Bryant, R. L. and Wilson, G. A., Rethinking environmental management. Progress in Human Geography, 22(3), pp. 321-343, 1998.

[22] Plummer, R. and Armitage, D., Crossing boundaries, crossing scales: the evolution of environment and resource co-management. Geography Compass, 1(4), pp. 834-849, 2007.

[23] de Loe, R., From Government to Governance: A State-or-the-Art Review of Environmental Governance. Report prepared for Alberta Environment, solicitation number 2009/ES-001, 2009.

[24] O’Connor, J., Natural Causes: Essays in Ecological Marxism. Guilford Press: New York, 1998.

[25] Wilbanks, T.J., Sustainable Development in Geographic Context. Annals, Association of American Geographers, 84, pp. 541-557, 1994.

[26] Glasbergen, P., The Question of Environmental Governance (Chapter 1). Co-operative Environmental Governance; Public-Private Agreements as Policy Strategy, ed P. Glasbergen Dordrecht, Kluwer Academic Publishers: The Netherlands, pp. 1-18, 1998.

[27] While, A., Littlewood, S., \& Whitney, D., New space for sustainable development? Regional environmental governance in the North West and the West Midlands of England. Town Planning Review, 71 (4), pp. 395$413,2000$.

[28] Gibbs, D., \& Jonas, E., Rescaling and regional governance: the English Regional Development Agencies and the environment. Environment and Planning C: Government and Policy, 19, pp. 269-288, 2001.

[29] Gibbs, D., Jonas, A., \& While, A., Changing governance structures and the environment: economy-environment relations at the local and regional scales. Journal of Environmental Policy and Planning, 4, pp. 123-138, 2002.

[30] Pahl-Wostl, C., Craps, M, Dewulf, A., Mostert, E., Tabara, D., \& Taillieu, T., Social learning and water resources management. Ecology and Society, 12(2), pp. 1-19, 2007. 
[31] Allan, Tony. (2003). IWRM/IWRMA: A New Sanctioned Discourse? SOAS Water Issues Study Group, University of London, Occasional paper \#50.

[32] Reddy, V.R., \& Reddy, P.P., How participatory is participatory irrigation management? Economic and Political Weekly, December, pp. 5587-5595, 2005.

[33] Pahl-Wostl, C., The importance of social learning in restoring the multifunctionality of rivers and floodplains. Ecology and Society, 11(5), pp. 10, 2006.

[34] Blomquist, W., \& Schlager, E., Political pitfalls of integrated watershed Management. Society and Natural Resources, 18, pp. 101-117, 2005.

[35] O'Riordan T., The challenge for environmentalism (Chapter 4). New Models in Geography: The Political-Economy Perspective, eds. R. Peet and N. Thrift, Unwin Hyman: United Kingdom, pp. 82-110, 1989.

[36] van Bueren, E.M., Klijn, E-H., Koppenjan, J.F.M., Dealing with wicked problems in networks: Analyzing an environmental debate from a network perspective. Journal of Public Administration Research and Theory, 13(2), pp. 193-212, 2003.

[37] Ferreyra, Cecilia, de Loe, R.C., \& Kreutzeiser, R.D., Imagined communities, contested watersheds: Challenges in integrated water resources management in agricultural areas. Journal of Rural Studies, 24, pp. 304-321, 2008.

[38] Steinacker, Annette, Game-theoretic models of metropolitan cooperation (Chapter 4). Metropolitan Governance: Conflict, Competition and Cooperation, ed. Richard Feiock, Georgetown University Press: Washington, pp. 46-56, 2004.

[39] Cervoni, L., Biro, A., \& Beazley, K., Implementing Integrated Water Resources Management: The Importance of Cross-Scale Considerations and Local Conditions in Ontario and Nova Scotia. Canadian Water Resources Journal, 33(4), pp. 333-350, 2008.

[40] Mitchell, B., Integrated water resource management, institutional arrangements, and land-use planning. Environment and Planning A, 37, pp. 1335-1352, 2005.

[41] Biswas, Asit, K., Integrated water resources management: A reassessment. Water International, 29(2), pp. 248-256, 2004.

[42] Carter, N., Kreutzwiser, R.D., \& de Loë, R.C., Closing the circle: linking land use planning and water management at the local level. Land Use Policy, 22(2), pp. 115-127, 2005.

[43] Leach, William \& Pelkey, Neil, Making watershed partnerships work: A review of the empirical literature. Journal of Water Resources Planning and Management, November/December, pp. 378-385, 2001.

[44] Sorensen, Marianne, Calgary Regional Partnership: Economic and Social Profile. City-Region Studies Centre, University of Alberta, Faculty of Extension, 2009.

[45] Calgary Regional Partnership (CRP). Most Recent CRP Messaging Regarding the Calgary Metropolitan Plan, November, 2009. 
562 The Sustainable City VII, Vol. 1

[46] Calgary Regional Partnership (CRP). General Assembly, June, 19. 2009.

[47] Wenig, Michael, L., Understanding Local Albertans' Roles in Watershed Planning - Will the Real Blueprint Please Step Forward? Canadian Institute of Resources Law, Occasional Paper \#28, 2010. 